\title{
Medical device legislation for custom-made devices after the UK has left the EU: answers to ten important questions
}

\author{
James I. J. Green ${ }^{1,2}$
}

\section{Key points}

Examines the background to medical device legislation pertinent to custom-made devices.
Considers the impact that the UK's withdrawal from the EU and the COVID-19 pandemic has had upon the new Medical Device Regulations.
Highlights the obligations that relate to dental professionals who prescribe and manufacture custom-made devices.

\begin{abstract}
The 1990s saw the introduction of three European directives that aimed to harmonise medical device legislation within the European Union (EU), which were given effect in the UK by The Medical Devices Regulations 2002 (Statutory Instrument 2002/618). Dental professionals who prescribe and manufacture custom-made devices were required to do so in accordance with the relevant requirements of one of these directives, Council Directive 93/42/ EEC (Medical Device Directive [MDD]). The MDD has been replaced by Regulation (EU) 2017/745 (Medical Device Regulation [EU MDR]) and this paper answers some important questions regarding the ways in which this affects the provision of custom-made devices in a dental setting.
\end{abstract}

\section{Introduction}

Three European directives - Council Directive 90/385/EEC of 20 June 1990 on the approximation of the laws of the Member States relating to active implantable medical devices (Active Implantable Medical Devices Directive [AIMDD]), ${ }^{1}$ Council Directive 93/42/EEC of 14 June 1993 concerning medical devices (Medical Device Directive [MDD] ${ }^{2}$ and Directive 98/79/EC of the European Parliament and of the Council of 27 October 1998 on in vitro diagnostic medical devices (In Vitro Diagnostic Medical Devices Directive [IVDMDD] $)^{3}$ - were introduced in the 1990s with the aim of harmonising medical device

${ }^{1}$ Maxillofacial and Dental Laboratory Manager, Great Ormond Street Hospital for Children NHS Foundation Trust, London, UK; ${ }^{2}$ Broomfield Hospital, Mid and South Essex NHS Foundation Trust, Chelmsford, UK.

Correspondence to: James I. J. Green

Email address: jamesgreen@nhs.net

Refereed Paper.

Accepted 14 December 2020

https://doi.org/10.1038/s41415-021-3530-x legislation within the European Union (EU).

These Directives, and the later amendment Directive 2007/47/EC, ${ }^{4}$ were given effect in the UK by The Medical Devices Regulations 2002 (Statutory Instrument 2002/618) and its amendments, The Medical Devices (Amendment) Regulations 2003 (SI 2003/1697) ${ }^{6}$ and The Medical Devices (Amendment) Regulations 2008 (SI 2008/2936). ${ }^{7}$

Dental professionals who prescribe and/ or manufacture custom-made devices were required to do so in accordance with the relevant requirements of the MDD. The MDD was replaced by Regulation (EU) 2017/745 (Medical Device Regulation [EU MDR]), ${ }^{8}$ which was due to be fully implemented on 26 May 2020. However, in April 2020, Regulation (EU) 2020/561 was adopted, which deferred this for one year until 26 May 2021 , so that efforts could be concentrated on the response to the coronavirus disease 2019 (COVID-19) pandemic. ${ }^{9}$

The UK left the EU on 31 January 2020 and entered an 11-month implementation period (IP), during which EU law continued to apply. In preparation for the UK's withdrawal from the EU, Regulation (EU) 2017/745 was largely transposed into The Medical Devices (Amendment etc) (EU Exit) Regulations 2019,10 (Statutory Instrument 2019/791 [UK MDR 2019], an amendment of the UK MDR 2002 ${ }^{4}$ ) and was expected to be fully implemented on exit day. However, the UK MDR was further amended by The Medical Devices (Amendment etc) (EU Exit) Regulations 2020 (Statutory Instrument 2020/1478 [UK MDR 2020]), which essentially removed the provisions of the EU MDR and substituted 'exit day' for 'IP completion day' ${ }^{11}$

In Great Britain, from 1 January 2021, medical devices must conform to The Medical Devices Regulations 2002 (in the form in which they exist on 1 January 2021) or the EU MDR (until 30 June 2023). Northern Ireland remains in line with the EU legislation and implementation timeline ${ }^{12}$ under the terms of the protocol on Ireland/ Northern Ireland. ${ }^{13}$ 
Table 1 Definitions given in medical device legislation that are pertinent to this paper (cont. on page 515)

\section{Great Britain}

The Medical Devices Regulations 2002 (Statutory Instrument $2002 / 618)^{5}$ (as amended) ${ }^{10,11}$

A conformity marking consisting of the initials ' $C E$ '; 'the Community' means:

CE marking of conformity (a) in the context of any requirement relating to an in vitro diagnostic medical device, the European Community;

(b) in the context of any requirement relating to any other medical device, the European Economic Area

A relevant device that is:

(a) manufactured specifically in accordance with a written

Custom-made device prescription of a duly qualified medical practitioner or a professional user which gives, under his responsibility, specific characteristics as to its design; and

(b) intended for the sole use of a particular patient, but does not include a mass-produced product which needs to be adapted to meet the specific requirements of the medical practitioner or professional user

\begin{tabular}{l|l}
\hline Fully refurbishing & - \\
\hline Health institution & -
\end{tabular}

(a) The person with responsibility for the design, manufacture, packaging and labelling of a device before it is placed on the market under their own name, regardless of whether these operations are carried out by that particular person or on their behalf by a third party; or

\begin{tabular}{l|l} 
Manufacturer & (b) Any other person who assembles, packages, processes, fully
\end{tabular} refurbishes or labels one or more ready-made product or assigns to them their intended purpose as a device with a view to their being placed on the market under their own name, apart from a person who assembles or adapts devices already on the market to their intended purpose for an individual patient

An instrument, apparatus, appliance, material or other article, whether used alone or in combination, together with any software necessary for its proper application, which:

(a) is intended by the manufacturer to be used for human beings for the purpose of-

(i) diagnosis, prevention, monitoring, treatment or alleviation of disease

(ii) diagnosis, monitoring, treatment, alleviation of or compensation for an injury or handicap

(iii) investigation, replacement or modification of the anatomy or of a physiological process, or

(iv) control of conception; and

\section{European Union and Northern Ireland}

Regulation (EU) $2017 / 745$ of the European Parliament and of the Council of 5 April 2017 on medical devices ${ }^{8}$

A marking by which a manufacturer indicates that a device is in conformity with the applicable requirements set out in this Regulation and other applicable Union harmonisation legislation providing for its affixing

Any device specifically made in accordance with a written prescription of any person authorised by national law by virtue of that person's professional qualifications which gives, under that person's responsibility, specific design characteristics, and is intended for the sole use of a particular patient exclusively to meet their individual conditions and needs

However, mass-produced devices which need to be adapted to meet the specific requirements of any professional user and devices which are mass-produced by means of industrial manufacturing processes in accordance with the written prescriptions of any authorised person shall not be considered to be custom-made devices

For the purposes of the definition of manufacturer, means the complete rebuilding of a device already placed on the market or put into service, or the making of a new device from used devices, to bring it into conformity with this Regulation, combined with the assignment of a new lifetime to the refurbished device

An organisation, the primary purpose of which is the care or treatment of patients or the promotion of public health

A natural or legal person who manufactures or fully refurbishes a device or has a device designed, manufactured or fully refurbished, and markets that device under its name or trademark

Any instrument, apparatus, appliance, software, implant, reagent material or other article intended by the manufacturer to be used, alone or in combination, for human beings for one or more of the following specific medical purposes:

(a) diagnosis, prevention, monitoring, prediction, prognosis, treatment or alleviation of disease,

(b) diagnosis, monitoring, treatment, alleviation of, or compensation for, an injury or disability,

(c) investigation, replacement or modification of the anatomy or of a physiological or pathological process or state

(d) providing information by means of in vitro examination of specimens derived from the human body, including organ, blood and tissue donations, and which does not achieve its principal intended action by pharmacological, immunological or metabolic means, in or on the human body, but which may be assisted in its function by such means. The following products shall also be deemed to be medical devices:

(i) devices for the control or support of conception 
Table 1 Definitions given in medical device legislation that are pertinent to this paper (cont. from page 514)

\section{Great Britain}

The Medical Devices Regulations 2002 (Statutory Instrument $2002 / 618)^{5}$ (as amended) ${ }^{10,11}$

(b) does not achieve its principal intended action in or on the human body by pharmacological, immunological or metabolic means, even if it is assisted in its function by such means, and includes devices intended to administer a medicinal product or which incorporate as an integral part a substance which, if used separately, would be a medicinal product and which is liable to act upon the body with action ancillary to that of the device

\begin{tabular}{|c|c|}
\hline Notified body & $\begin{array}{l}\text { A body authorised in acc } \\
\text { out tasks of a notified bc } \\
\text { Regulations or a mutual } \\
\text { conformity assessment } \\
\text { otherwise, does not incl }\end{array}$ \\
\hline Placing on the market & $\begin{array}{l}\text { In relation to a medical } \\
\text { for payment or free of } \\
\text { other than a device inter } \\
\text { to distribution, use, or b } \\
\text { expressions must be con }\end{array}$ \\
\hline $\begin{array}{l}\text { Unique Device Identifier } \\
\text { (UDI) }\end{array}$ & - \\
\hline \multicolumn{2}{|c|}{$\begin{array}{l}\text { 1. From a dental perspective, what } \\
\text { is a custom-made device? }\end{array}$} \\
\hline
\end{tabular}

Under medical device legislation, a custommade device is a medical device intended for the sole use of a particular patient. While its definition has been revised under the new legislation, the essential meaning of what defines a custom-made device remains the same (Table 1). In a dental context, custommade devices cover a wide variety of appliances and prostheses; Figure 1 provides examples of commonly prescribed custom-made devices in a dental setting.

\section{In terms of UK dental professionals, who prescribes custom-made devices?}

Custom-made devices are usually prescribed by a dentist, although clinical dental technicians can prescribe and provide complete dentures direct to patients. ${ }^{14}$

\section{In terms of UK dental professionals, who is the manufacturer of custom-made devices?}

In a typical dental scenario, the role of manufacturer will be shared by the prescriber and the dental professional who constructs the device (Table 1): the prescriber 'has a device

\section{European Union and Northern Ireland}

Regulation (EU) 2017/745 of the European Parliament and of the Council of 5 April 2017 on medical devices ${ }^{8}$

(ii) products specifically intended for the cleaning, disinfection or sterilisation of devices as referred to in Article 1(4) and of those referred to in the first paragraph of this point

A conformity assessment body designated in accordance with this Regulation

The first making available of a device, other than an investigational device, on the Union market

A series of numeric or alphanumeric characters that is created through internationally accepted device identification and coding standards, and that allows unambiguous identification of specific devices on the market
Fig. 1 Typical custom-made devices provided in a dental setting

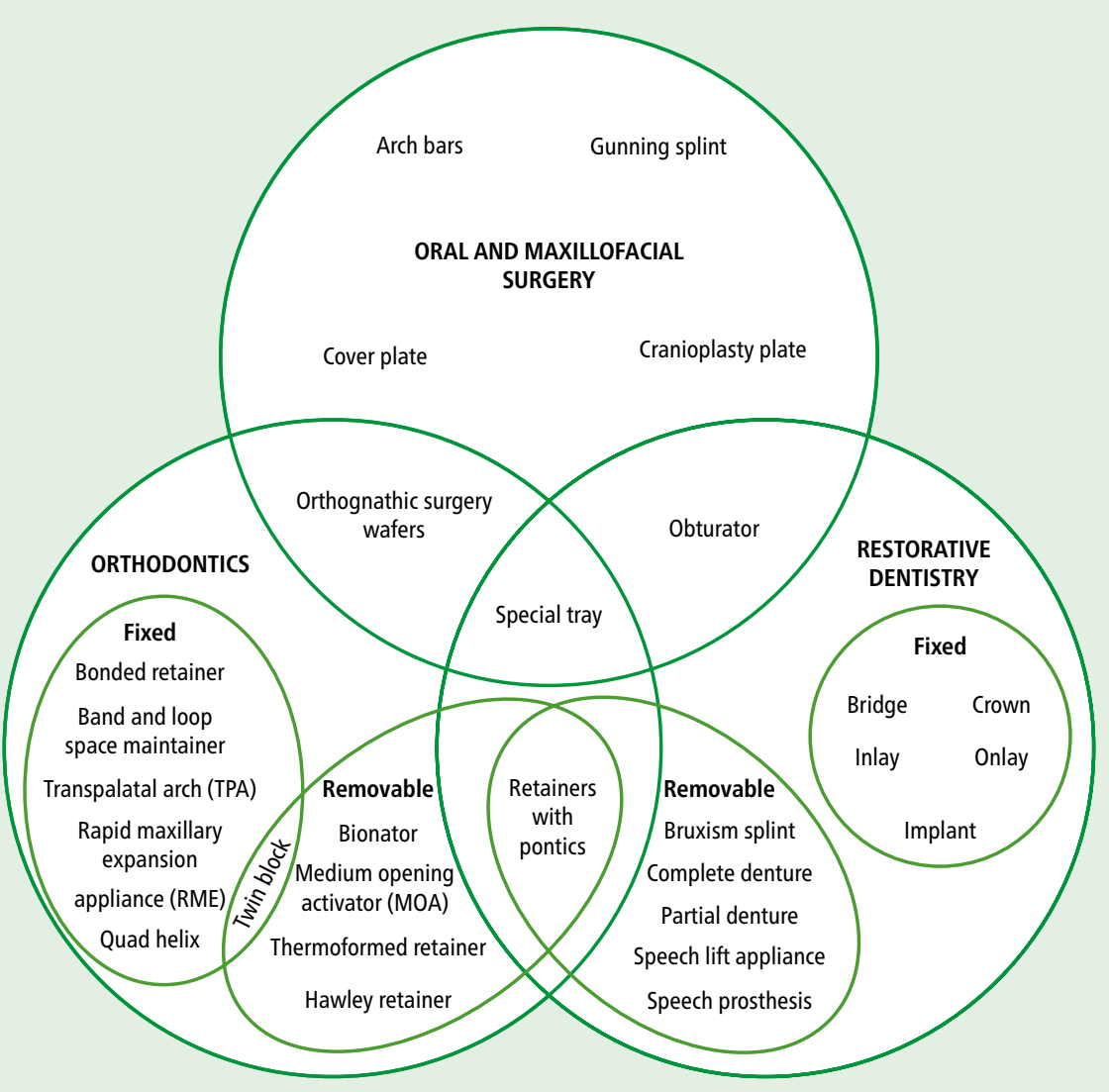


designed, manufactured or fully refurbished' while the constructor 'manufactures or fully refurbishes a device'. Custom-made devices in a dental context can be constructed by dental technicians, clinical dental technicians and dentists. Other dental professionals are permitted to construct certain custom-made devices, provided they are trained, competent and indemnified to do so. ${ }^{14}$ The medical device legislation that applies to devices fabricated by dental technicians in dental laboratories applies equally to devices constructed by other dental professionals in dental practices.

Table 2 summarises the aspects of the General Dental Council Scope of practice that can pertain to custom-made devices and indicates which registrants may undertake which procedures, if trained, competent and indemnified. A device repair will not fit within the definition of manufacturing unless the device has been fully refurbished. Procedures performed in order to fit a custom-made device such as preparation, impression taking, prescribing, final fitting and any adaptation are not considered to fall within the scope of the UK MDR. ${ }^{20}$

\section{Which requirements remain the same for providers of custom-made dental devices?}

The following requirements remain as they were under the MDD (see Table 3 for second point):

- Medical device manufacturers will continue to be required to inform the Medicines and Healthcare products Regulatory Agency (MHRA) before placing devices on the market

- Under the EU MDR, there are now 22 classification rules instead of 18 , but those for custom-made dental devices remain unchanged. Devices are classified according to risk level, which is based on factors including intended duration of use, intended purpose and invasiveness. Custom-made dental devices are categorised under Rule 5 (invasive devices intended to be used in the oral cavity as far as the pharynx) and Rule 8 (implantable devices and long-term surgically invasive devices)

- Under the MDD, manufacturers of custom-made devices were required to prepare documentation regarding the design, manufacture and performance of the devices they produce, which must be kept available for the MHRA (Annex VIII[3-3.1]). This obligation is unchanged under the EU MDR (Annex XIII[2-3]

- As before, custom-made device manufacturers must review and document experience gained in the post-production phase, and report serious incidents and field safety corrective actions. These obligations are given in EU MDR Annex XIII(5).

\section{Which new requirements relate to providers of custom-made dental devices?}

The EU MDR introduces numerous changes, some of which apply to custom-made dental devices $\left({ }^{\star}=\right.$ see Table $1,{ }^{*}=$ see Table 4$)$ :

- Under the MDD, devices manufactured within a health institution (defined here ${ }^{*}$ ) were not considered to have been placed on the market (also defined here ${ }^{\star}$ ) so were exempt from these requirements. ${ }^{15}$ This remains the case for health institutions in Great Britain but those in the EU and Northern Ireland that wish to maintain an exemption will now need to satisfy the conditions given in EU MDR Article 5(5) ${ }^{\star *}$

- Under the EU MDR, medical device manufacturers are now required to have a 'person responsible for regulatory compliance' in place (EU MDR Article 15), which is similar to the 'qualified person' in pharmaceuticals, who is responsible for the quality assurance of medicinal products

- Quality management obligations are much more explicitly defined in the EU MDR and are given in Article 10(9). The requirements correspond with parts of International Organisation for Standardisation (ISO) standard 13485 'Medical devices - quality management systems - requirements for regulatory purposes' 16

- Risk management requirements are also better defined. The General Safety and Performance Requirements provided in EU MDR Annex I, which replace the MDD Annex I Essential Requirements, include the requirement to establish, implement, document and maintain a risk management system. These obligations correlate with parts of ISO 14971 'Medical devices - application of risk management to medical devices' ${ }^{17}$

- The requisite information that must be included on the statement that accompanies custom-made dental devices is broadly as it was under the MDD, but there are additional requirements. In addition to the name and address of the manufacturer, the name and address of any additional manufacturing sites now need to be incorporated and, where applicable, the name and address of the authorised representative now need to be included (EU MDR Annex XIII[1])

- Custom-made device manufacturers were mandated to keep a copy of the statement that accompanies such devices for at least five years under the MDD. This has changed to at least ten years (EU MDR Annex XIII[4])

- The requirement for manufacturers outside the EU placing medical devices on the EU market to appoint an authorised representative remains the same, but with additional obligations (EU MDR Article 11). This also applies to manufacturers outside Northern Ireland who place medical devices on the Northern Ireland market. Manufacturers outside Great Britain who place devices on the Great Britain market are required to appoint a UK responsible person (UK MDR 2002 regulation 60 [as amended by the UK MDR 2019]).

As stated previously, in a typical dental setting, the role of manufacturer will be shared by the prescriber and constructor of the device. Table 5 provides a summary of the legislative obligations that relate to manufacturers of custom-made devices.

\section{What are the differences between the EU MDR and the UK MDR 2019?}

The EU MDR was essentially transposed into the UK MDR 2019, but with some minor changes:

- The word 'shall' was largely replaced with the word 'must'

- The main divisions in the UK MDR are called regulations while those in the EU MDR are named articles

- In UK legislation, any consequential or supplementary provisions that appear after the main divisions are set out in schedules. The EU legislative equivalent to schedules are known as annexes

- The subdivisions of the schedules in the UK MDR are named paragraphs but those in the EU MDR Annexes are called sections. 
Table 2 Aspects of the General Dental Council Scope of practice that can pertain to custom-made devices, indicating which of its registrants may undertake which procedures, if trained, competent and indemnified ${ }^{14}$

\begin{tabular}{|c|c|c|c|c|c|c|c|}
\hline Procedure & $\begin{array}{l}\text { Dental } \\
\text { nurses }\end{array}$ & $\begin{array}{l}\text { Orthodontic } \\
\text { therapists }\end{array}$ & $\begin{array}{l}\text { Dental } \\
\text { hygienists }\end{array}$ & $\begin{array}{l}\text { Dental } \\
\text { therapists }\end{array}$ & $\begin{array}{l}\text { Dental } \\
\text { technicians }\end{array}$ & $\begin{array}{l}\text { Clinical dental } \\
\text { technicians }\end{array}$ & Dentists \\
\hline $\begin{array}{l}\text { Perform technical and clinical procedures related to providing } \\
\text { removable dental appliances }\end{array}$ & & & & & & G & $\checkmark$ \\
\hline $\begin{array}{l}\text { Work with the dentist or clinical dental technician on treatment } \\
\text { planning and outline design }\end{array}$ & & & & & $\checkmark$ & $\checkmark$ & $\checkmark$ \\
\hline $\begin{array}{l}\text { Design, plan and make a range of custom-made dental devices } \\
\text { according to a prescription }\end{array}$ & & & & & $\checkmark$ & $\checkmark$ & $\checkmark$ \\
\hline Take impressions & A & D & $\checkmark$ & $\checkmark$ & $\mathrm{F}$ & G & $\checkmark$ \\
\hline Carry out intraoral scanning for CAD/CAM & & & & & $\mathrm{F}$ & G & $\checkmark$ \\
\hline $\begin{array}{l}\text { Take and process radiographs and other images related to } \\
\text { providing removable dental appliances }\end{array}$ & & & & & & G & $\checkmark$ \\
\hline Take occlusal registrations & & D & & & $\mathrm{F}$ & G & $\checkmark$ \\
\hline Take orthognathic facebow readings & & D & & & E & $\mathrm{F}$ & $\checkmark$ \\
\hline Carry out shade taking & B & & & & $\checkmark$ & $\checkmark$ & $\checkmark$ \\
\hline Pour, cast and trim study models & B & D & & & $\checkmark$ & $\checkmark$ & $\checkmark$ \\
\hline Prescribe and provide fixed orthodontic treatment & & & & & & & $\checkmark$ \\
\hline Prescribe and provide fixed and removable prostheses & & & & & & & $\checkmark$ \\
\hline Prescribe and provide complete dentures direct to patients & & & & & & $\checkmark$ & $\checkmark$ \\
\hline Prescribe and provide crowns and bridges & & & & & & & $\checkmark$ \\
\hline Construct occlusal registration rims and special trays & $c$ & & & & $\checkmark$ & $\checkmark$ & $\checkmark$ \\
\hline Construct vacuum-formed retainers to the prescription of a dentist & C & & & & $\checkmark$ & $\checkmark$ & $\checkmark$ \\
\hline Construct mouthguards to the prescription of a dentist & C & & & & $\checkmark$ & $\checkmark$ & $\checkmark$ \\
\hline Provide sports mouthguards & & & & & & $\checkmark$ & $\checkmark$ \\
\hline Provide anti-snoring devices on prescription of a dentist & & & & & & $\mathrm{H}$ & $\checkmark$ \\
\hline Provide and fit other dental devices on prescription of a dentist & & & & & & $\checkmark$ & $\checkmark$ \\
\hline $\begin{array}{l}\text { Modify dental devices including dentures, orthodontic } \\
\text { appliances, crowns and bridges according to a prescription }\end{array}$ & & & & & $\checkmark$ & $\checkmark$ & $\checkmark$ \\
\hline Fit removable appliances & & & & & & G & $\checkmark$ \\
\hline Insert passive removable orthodontic appliances & & D & & & & D & $\checkmark$ \\
\hline Insert removable appliances activated or adjusted by a dentist & & D & & & & D & $\checkmark$ \\
\hline Fit bonded retainers & & D & & & & & $\checkmark$ \\
\hline $\begin{array}{l}\text { Make a patient's orthodontic appliance safe in the absence of } \\
\text { a dentist }\end{array}$ & & D & & & & & N/A \\
\hline Re-cement crowns with temporary cement & & & $\checkmark$ & $\checkmark$ & & $\mathrm{H}$ & $\checkmark$ \\
\hline Replace implant abutments for removable dental appliances & & & & & & $\mathrm{H}$ & $\checkmark$ \\
\hline Remove fixed appliances & & D & & & & & $\checkmark$ \\
\hline Repair dentures direct to patients & & & & & $\checkmark$ & $\checkmark$ & $\checkmark$ \\
\hline Repair the acrylic component of removable appliances & c & & & & $\checkmark$ & $\checkmark$ & $\checkmark$ \\
\hline Repair the acrylic component part of orthodontic appliances & & E & & & $\checkmark$ & $\checkmark$ & $\checkmark$ \\
\hline \multicolumn{8}{|c|}{$\begin{array}{l}\text { Key: } \\
A=\text { an additional skill that dental nurses could develop, carried out to the prescription of, or under the direction of, a dentist or a clinical dental technician (where appropriate). } \\
B=\text { additional skills that dental nurses could develop. } \\
C=\text { additional skills carried out on prescription from, or under the direction of, another registrant. } \\
D=\text { under prescription from a dentist. } \\
E=\text { an additional skill that orthodontic therapists could develop. } \\
F=\text { additional skills that dental technicians could develop, working with a dentist or a clinical dental technician in the clinic, assisting with treatment. } \\
G=\text { under prescription from a dentist, unless for complete dentures. } \\
H=\text { an additional skill that clinical dental technicians could develop. }\end{array}$} \\
\hline
\end{tabular}




\begin{tabular}{|c|c|c|c|c|c|}
\hline \multicolumn{2}{|l|}{ Class I } & \multicolumn{2}{|l|}{ Class Ila } & Class IIb & Class III \\
\hline \multicolumn{2}{|c|}{ Generally considered low risk } & \multicolumn{2}{|l|}{ Generally considered moderate risk } & $\begin{array}{l}\text { Generally considered } \\
\text { potentially high risk }\end{array}$ & $\begin{array}{l}\text { Generally considered } \\
\text { high risk }\end{array}$ \\
\hline \multicolumn{3}{|l|}{ Rule 5} & \multicolumn{2}{|l|}{ Rule 8} & \\
\hline \multicolumn{3}{|c|}{$\begin{array}{l}\text { Invasive devices with respect to body orifices, other than surgically invasive devices, which } \\
\text { are not intended for connection to an active medical device or which are intended for } \\
\text { connection to a Class I active device }\end{array}$} & \multicolumn{2}{|c|}{$\begin{array}{l}\text { Implantable devices and long-term surgically } \\
\text { invasive devices }\end{array}$} & \\
\hline \multicolumn{3}{|c|}{ Used in the oral cavity as far as the pharynx } & \multicolumn{2}{|l|}{ Placed in the teeth } & \\
\hline Transient & Short-term & \multicolumn{3}{|l|}{ Long-term } & \\
\hline $\begin{array}{l}\text { Normally intended for } \\
\text { continuous use for less } \\
\text { than } 60 \text { minutes }\end{array}$ & $\begin{array}{l}\text { Normally intended for } \\
\text { continuous use for between } \\
60 \text { minutes and } 30 \text { days }\end{array}$ & \multicolumn{3}{|c|}{ Normally intended for continuous use for more than 30 days } & \\
\hline $\begin{array}{l}\text { Special tray, intermediate } \\
\text { orthognathic wafer }\end{array}$ & $\begin{array}{l}\text { Arch bars, final orthognathic } \\
\text { wafer }\end{array}$ & $\begin{array}{l}\text { Denture, obturator, orthodontic } \\
\text { appliance, speech lift } \\
\text { appliance, speech prosthesis }\end{array}$ & $\begin{array}{l}\text { Crown, bridge, } \\
\text { inlay, onlay }\end{array}$ & $\begin{array}{l}\text { Cranioplasty plate, dental } \\
\text { implant }\end{array}$ & \\
\hline
\end{tabular}

\section{Table 4 Exemption conditions for health institutions}

\section{Regulation (EU) 2017/745 of the European Parliament and of the Council of 5 April 2017 on medical devices ${ }^{8}$}

\section{Article 5(5)}

With the exception of the relevant general safety and performance requirements set out in Annex I, the requirements of this Regulation shall not apply to devices, manufactured and used only within health institutions established in the Union, provided that all of the following conditions are met:

\begin{tabular}{l|l}
\hline (a) & The devices are not transferred to another legal entity \\
\hline (b) & Manufacture and use of the devices occur under appropriate quality management systems \\
\hline (c) & $\begin{array}{l}\text { The health institution justifies in its documentation that the target patient group's specific needs cannot be met, or cannot be met at the } \\
\text { appropriate level of performance by an equivalent device available on the market }\end{array}$ \\
\hline (d) & $\begin{array}{l}\text { The health institution provides information upon request on the use of such devices to its competent authority, which shall include a justification of } \\
\text { their manufacturing, modification and use }\end{array}$
\end{tabular}

The health institution draws up a declaration which it shall make publicly available, including:

(i) The name and address of the manufacturing health institution

(e)

(ii) The details necessary to identify the devices

(iii) A declaration that the devices meet the general safety and performance requirements set out in Annex I to this Regulation and, where applicable, information on which requirements are not fully met with a reasoned justification therefore

The health institution draws up documentation that makes it possible to have an understanding of the manufacturing facility, the manufacturing process, the design and performance data of the devices, including the intended purpose, and that is sufficiently detailed to enable the competent authority to ascertain that the general safety and performance requirements set out in Annex I to this Regulation are met 


\begin{tabular}{|c|c|c|c|}
\hline & \multirow{2}{*}{$\begin{array}{l}\text { Great Britain } \\
\text { The Medical Devices Regulations } 2002 \\
\text { (Statutory Instrument 2002/618) } \text { (as amended) }^{10,11}\end{array}$} & \multirow{2}{*}{$\begin{array}{l}\text { European Union and Northern Ireland } \\
\text { Regulation (EU) } 2017 / 745 \text { of the } \\
\text { European Parliament and of the } \\
\text { Council of } 5 \text { April } 2017 \text { on medical } \\
\text { devices }^{8}\end{array}$} \\
\hline & & & \\
\hline 1 & $\begin{array}{l}\text { Register with the Medicines and Healthcare } \\
\text { products Regulatory Agency (MHRA) }\end{array}$ & Regulation 19(1a) & Article 21(2) \\
\hline 2 & $\begin{array}{l}\text { Appoint a person responsible for regulatory } \\
\text { compliance (PRRC) }\end{array}$ & - & Article 15 \\
\hline \multirow[b]{2}{*}{3} & $\begin{array}{l}\text { Manufacturers outside Great Britain placing } \\
\text { devices on the Great Britain market: appoint a UK } \\
\text { responsible person }\end{array}$ & Regulation 60 & - \\
\hline & $\begin{array}{l}\text { Manufacturers outside the European Union (EU) } \\
\text { or Northern Ireland placing devices on the EU or } \\
\text { Northern Ireland market: appoint an authorised } \\
\text { representative in the EU or Northern Ireland }\end{array}$ & - & Article 11 \\
\hline 4 & $\begin{array}{l}\text { Establish, document, implement and maintain, } \\
\text { keep up to date and continually improve a quality } \\
\text { management system }\end{array}$ & - & Article 10(9) \\
\hline 5 & $\begin{array}{l}\text { Comply with Annex I requirements applicable to } \\
\text { custom-made devices }\end{array}$ & $\begin{array}{l}\text { Regulation 8; MDD Annex I (as modified by the UK MDR } \\
\text { 2002) }\end{array}$ & Annex I \\
\hline 6 & Formulate technical documentation & $\begin{array}{l}\text { Regulation 15, paragraph (b) (c); MDD Annex VIII (3-3.1) } \\
\text { (as modified by the UK MDR 2002) }\end{array}$ & Annex XIII(2-3) \\
\hline 7 & Formulate statement of manufacture & $\begin{array}{l}\text { Regulation 15(a); MDD Annex VIII (2.1) (as modified by the } \\
\text { UK MDR 2002) }\end{array}$ & Annex XIII(1) \\
\hline 8 & Retain copy of the statement of manufacture & $\begin{array}{l}\text { Regulation 15(d); MDD Annex VIII (4) (as modified by the } \\
\text { UK MDR 2002) }\end{array}$ & Annex XIII(4) \\
\hline \multirow{2}{*}{9} & \multirow{2}{*}{$\begin{array}{l}\text { Review and document experience gained in the } \\
\text { post-production phase }\end{array}$} & MDD Annex X (as modified by the UK MDR 2002) & Annex XIV(5-8) \\
\hline & & \multirow{2}{*}{ MDD Annex VIII(5) (as modified by the UK MDR 2002) } & Annex XIII(5) \\
\hline 10 & $\begin{array}{l}\text { Report serious incidents and field safety corrective } \\
\text { actions }\end{array}$ & & Article 87 \\
\hline
\end{tabular}

\section{Will custom-made devices need to be registered with the new unique device identification system for medical devices?}

One of the most significant changes is the introduction of a unique device identification system for medical devices based on a Unique Device Identifier (UDI) (definition given in Table 1). The identification system aims to improve the traceability and postmarket safety-related activities of medical devices, but does not apply to custom-made devices (Table 6).

\section{Do custom-made devices need to bear the CE marking of conformity?}

The CE marking (defined in Table 1) is a certification mark that is used to indicate conformity with health, safety and environmental standards for products sold within the European Economic Area. The letters 'CE' stand for 'Conformité Européenne' (French for 'European Conformity'). Custom-made devices were not required to carry the CE marking under the MDD and this remains the same under the EU MDR (Table 7). In Great Britain, the CE marking is being replaced by the UKCA marking. ${ }^{18}$

\section{Do custom-made devices require the intervention of a notified body?}

A notified body (also referred to as a UK-approved body in the UK) (defined in Table 1) assesses whether medical devices meet the legal requirements. ${ }^{19}$ Under the new legislation, notified bodies have extended obligations and face greater supervision. However, custom-made devices do not require the intervention of a notified body. ${ }^{20}$
Table 6 Unique Device Identification (UDI) system exemption for custom-made devices

Regulation (EU) 2017/745 of the European Parliament and of the Council of 5 April 2017 on medical devices ${ }^{8}$

Article 27(3)

Before placing a device, other than a custom-made device, on the market, the manufacturer shall assign to the device and, if applicable, to all higher levels of packaging a UDI created in compliance with the rules of the issuing entity designated by the Commission in accordance with paragraph 2

Before a device, other than a custom-made or investigational device, is placed on the market, the manufacturer shall ensure that the information referred to in Part B of Annex VI of the device in question is correctly submitted and transferred to the UDI database referred to in Article 28 
Table 7 CE marking of conformity exemption for custom-made devices

\section{Great Britain}

The Medical Devices Regulations 2002 (Statutory Instrument 2002/618) ${ }^{5}$

Regulation 12(2)

Regulation 10 (CE marking of general medical devices) shall not apply to a custommade device or a device intended for clinical investigation
European Union and Northern Ireland

Regulation (EU) 2017/745 of the European Parliament and of the Council of 5 April 2017 on medical devices ${ }^{8}$

Article 20(1)

Devices, other than custom-made or investigational devices, considered to be in conformity with the requirements of this Regulation shall bear the CE marking of conformity

Table 8 Products without an intended medical purpose

Regulation (EU) 2017/745 of the European Parliament and of the Council of 5 April 2017 on medical devices, ${ }^{8}$ Annex XVI

1 Contact lenses or other items intended to be introduced into or onto the eye

2 Products intended to be totally or partially introduced into the human body through surgically invasive means for the purpose of modifying the anatomy or fixation of body parts, with the exception of tattooing products and piercings

Substances, combinations of substances, or items intended to be used for facial or other dermal or mucous membrane filling by subcutaneous, submucous or intradermal injection or other introduction, excluding those for tattooing

$4 \quad$ Equipment intended to be used to reduce, remove or destroy adipose tissue, such as equipment for liposuction, lipolysis or lipoplasty

High-intensity electromagnetic radiation (eg infrared, visible light and ultraviolet) emitting equipment intended for use on the human body, including

5 coherent and non-coherent sources, monochromatic and broad spectrum, such as lasers and intense pulsed light equipment, for skin resurfacing, tattoo or hair removal or other skin treatment

6

Equipment intended for brain stimulation that apply electrical currents or magnetic or electromagnetic fields that penetrate the cranium to modify neuronal activity in the brain

\section{Do tooth-whitening trays fall under the jurisdiction of the MDR?}

Tooth-whitening trays do not fall under the definition of a medical device (Table 1). Unlike the MDD, the EU MDR regulates medical devices that are similar to medical devices in terms of their function and risk level, but do not have an intended medical purpose. EU MDR Annex XVI lists the products without an intended medical purpose (Table 8), but tooth-whitening trays do not fall under this category either so they continue to be outside the jurisdiction of the MDR.

\section{Conclusion}

The regulations that govern medical devices in the UK and the EU have recently undergone a period of transition, which became more complex due to the UK's departure from the EU and the COVID19 pandemic. This paper answers some important questions for dental professionals who provide custom-made devices but is not a substitute for reading the legislation itself.
Ethics declaration

The author declares no conflict of interest.

\section{References}

1. Council of the European Communities. Council Directive 90/385/EEC of 20 June 1990 on the approximation of the laws of the Member States relating to active implantable medical devices. 1990. Available at https://eur-lex.europa.eu/legal-content/EN/TXT/ PDF/?uri=CELEX:31990L0385\&from=EN (accessed September 2020).

2. Council of the European Communities. Council Directive 93/42/EEC of 14 June 1993 concerning medical devices. 1993. Available at https:// eur-lex.europa.eu/legal-content/EN/TXT/ PDF/?uri=CELEX:31993L0042\&from=EN (accessed September 2020).

3. European Parliament/European Council. Directive 98/79/EC of the European Parliament and of the Council of 27 October 1998 on in vitro diagnostic medical devices. 1998. Available at https:// eur-lex.europa.eu/LexUriServ/LexUriServ. do? uri=CONSLEG:1998L0079:20090807:EN:PDF (accessed September 2020).

4. European Parliament/European Council. Directive 2007/47/EC of the European Parliament and of the Council of 5 September 2007 amending Council Directive 90/385/EEC on the approximation of the laws of the Member States relating to active implantable medical devices, Council Directive 93/42/EEC concerning medical devices and Directive 98/8/EC concerning the placing of biocidal products on the market. 2007. Available at https://eur-lex.europa.eu/legal-content/EN/TXT/ PDF/?uri=CELEX:32007L0047\&from=en (accessed September 2021).

5. Statutory Instruments. The Medical Devices Regulations 2002. 2002. Available at https://www.legislation. gov.uk/uksi/2002/618/pdfs/uksi_20020618_en.pdf (accessed September 2020).

6. Statutory Instruments. The Medical Devices (Amendment) Regulations 2003. 2003. Available at https://www.legislation.gov.uk/uksi/2003/1697/pdfs/ uksi_20031697_en.pdf (accessed September 2020).

7. Statutory Instruments. The Medical Devices (Amendment) Regulations 2008. 2008. Available at https://www.legislation.gov.uk/uksi/2008/2936/pdfs/ uksi_20082936 en.pdf (accessed September 2020).

8. European Parliament/European Council. Regulation (EU) 2017/745 of the European Parliament and of the Council of 5 April 2017 on medical devices, amending Directive 2001/83/EC, Regulation (EC) No 178/2002 and Regulation (EC) No 1223/2009 and repealing Council Directives 90/385/EEC and 93/42/EEC. 2017. Available at https://eur-lex.europa.eu/legal-content/EN/TXT/ PDF/?uri=CELEX:32017R0745 (accessed September 2020).

9. European Parliament/European Council. Regulation (EU) 2020/561 of the European Parliament and of the Council of 23 April 2020 amending Regulation (EU) $2017 / 745$ on medical devices, as regards the dates of application of certain of its provisions. 2020. Available at https://eur-lex.europa.eu/legal-content/EN/TXT/ PDF/?uri=CELEX:32020R0561\&from=EN (accessed September 2020).

10. Statutory Instruments. The Medical Devices (Amendment etc.) (EU Exit) Regulations 2019. 2019. 2019. Available at https://www.legislation.gov.uk/ uksi/2019/791/pdfs/uksi_20190791_en.pdf (accessed September 2021).

11. Statutory Instruments. The Medical Devices (Amendment etc.) (EU Exit) Regulations 2020 2020. Available at https://www.legislation.gov.uk/ uksi/2020/1478/pdfs/uksi_20201478_en.pdf (accessed September 2021).

12. Medicines and Healthcare products Regulatory Agency. Regulating medical devices in the UK. 2020. Available at https://www.gov.uk/guidance/ 
regulating-medical-devices-from-1-january-2021 (accessed September 2021).

13. UK Government. Protocol on Ireland/Northern Ireland. Available at https://assets. publishing.service. gov.uk/government/uploads/system/uploads/ attachment data/file/840230/Revised_Protocol to the_Withdrawal_Agreement.pdf (accessed September 2021).

14. General Dental Council. Scope of Practice. 2013 Available at https://www.gdc-uk.org/docs/defaultsource/scope-of-practice/scope-of-practice.pdf (accessed September 2020).

15. Medicines and Healthcare products Regulatory Agency. In-house manufacture of medical devices in
Great Britain. 2014. Available at https://www.gov.uk/ government/publications/in-house-manufacture-ofmedical-devices/in-house-manufacture-of-medicaldevices (accessed September 2021).

16. International Organisation for Standardisation. ISO 13485:2016 Medical devices - Quality management systems - Requirements for regulatory purposes. 2016 Available at https://www.iso.org/standard/59752.html (accessed September 2021).

17. International Organisation for Standardisation. ISO 14971:2019 Medical devices - Application of risk management to medical devices. 2019. Available at https://www.iso.org/obp/ui\#iso:std:iso:14971:ed3:v1:en (accessed September 2021).
18. Department for Business, Energy \& Industrial Strategy. Using the UKCA marking. 2020. Available at https:// www.gov.uk/guidance/using-the-ukca-marking (accessed September 2021).

19. Medicines and Healthcare products Regulatory Agency. Approved bodies for medical devices. 2020. Available at https://www.gov.uk/government/publications/ approved-bodies-for-medical-devices (accessed September 2021).

20. Medicines and Healthcare products Regulatory Agency. Custom-made devices in Great Britain. 2020. Available at https://www.gov.uk/government/publications/ custom-made-medical-devices/custom-made-devicesin-great-britain (accessed September 2020). 